\title{
Flasher: Exploring the Mind of an Exhibitionist
}

Amanda, P.

English for Creative Industry, Faculty of Letters, Petra Christian University, Siwalankerto 121-131, Surabaya 60236, East Java, INDONESIA

Emails: m11413002@john.petra.ac.id

\begin{abstract}
Exhibitionism is a mental disorder characterized by compulsive disorder for exhibiting genital to an unsuspecting stranger. Through my creative work, I would like to raise awareness about exhibitionism for all readers, especially Indonesian people. I hope after reading my screenplay, readers will be able to understand more about exhibitionism. My screenplay explores the struggle of an exhibitionist to repress his desire to exhibit and his effort to change into a "normal" person sexually through Peter, my main character. The story goes around Peter who is an exhibitionist that is struggling with his desire to expose his genital to his victims while he does not really accept his sexual deviation which resulted internal conflict inside him. Later, he meets a girl that he really likes which makes him motivated to change. He tries his best to change before the girl realizes that there is something else about him.
\end{abstract}

Keywords: Psychological problems, Sexual deviation, Exhibitionism, Drama

\section{INTRODUCTION}

Writers have a lot of choices for writing an idea into a form of creative work. I prefer to write my idea into the form of screenplay since I am interested in filmmaking. I feel more comfortable making my idea into a screenplay because it can be used to test the characters and the structure by filming it into a film (Bonnet, n.d). Actors and/or actresses need to act out the characters in the story to test whether the characters are realistic enough or not since it will be visualized into a film. The same thing goes for the structure of the story. We can test the plot through filming it since we can see the real visualization, not only imagining it. Since my story needs strong visualization, writing a screenplay is a better choice for me. The visualization of the creepiness and dark atmosphere can be seen vividly through film. Readers are able to feel the situation and the feeling of the characters way more clearly by focusing more into the visualization since the exposition has to be shown through images in the film rather than words.

The story of my screenplay deals with paraphilic disorder. Paraphilic disorders are recurrent, intense, sexually arousing fantasies, urges, or behaviors that are distressing or disabling and that involve inanimate objects, children or non-consenting adults, or suffering or humiliation of oneself or the partner with the potential to cause harm (Brown, 2015). A person is said to have a paraphilia when he or she feels sexually aroused by an object or activity that most people don't find arousing. Some common examples of paraphilias are pedophilia, voyeurism, transvestic fetishism, exhibitionism, sexual masochism disorder and sexual sadism disorder (Brown, 2015).

Through this creative work, I want to focus more on exhibitionism. According to George R. Brown (2015), exhibitionism is characterized by achievement of sexual excitement through genital exposure, usually to an unsuspecting stranger. It may also refer to a strong desire to be observed by other people during sexual activity. Exhibitionistic disorder involves acting on these urges with a non-consenting 
person or experiencing significant distress or functional impairment because of such urges and impulses (Brown, 2015).

Exhibitionists (usually male) may masturbate while exposing or fantasizing about exposing themselves to others. They may be aware of their need to surprise, shock, or impress the unwilling observer. The victim is almost always a female adult or a child of either sex (Brown, 2015). Though most instances of exhibitionism are never reported to authorities, the act itself qualifies as an incident of "indecent exposure," a misdemeanor crime whose punishment varies greatly by region in the United States (Sex Info Online, 2014).

My story is about a male exhibitionist, named Peter who is struggling with his desire to expose his genital to his victims while he does not really accept his sexual deviation which resulted internal conflict inside him. Later, he meets a girl, named Camila that he really likes which makes him motivated to change. He tries his best to change before the girl realizes that there is something else about him.

Through my creative work, I want to focus on how exhibitionists deal with their disorder while having to live a "normal life" according to the society standard. In the context of my story, I want to explore: How Peter deals with his disorder while having to live a "normal life" according to the society's standard.

The purposes of this creative work are to be able to understand exhibitionism behavior better, the struggle of exhibitionist to have a "normal" life and their effort to treat their disorder. In the context of my story, I want to show:

Peter's effort to fight his disorder by repressing his desire to exhibit and going under long term treatment of medication.

Hopefully, by using exhibitionism as the subject for my screenplay, I can give a fresh entertainment or even an idea for the readers or maybe the audiences in the future since there is only one exhibitionism film so far, titled The Exhibitionist Files (Byrne \& Lazarus, 2002). Also, since exhibitionism is rarely exposed in Indonesia, there is not any Indonesian film that talks about exhibitionism. Therefore, I hope this screenplay will be something new and educative for Indonesian readers.

I also hope after reading my screenplay, Indonesian people become more aware with exhibitionism issues. I hope they realize that it is one of the types of severe psychological problems that actually can be cured by going under long term treatment of medication. Hopefully, this film may encourage them to learn how to treat exhibitionist in order to help them to have normal life by giving them support, not by treating them as an outcast instead.

\section{OUTLINE OF THE CREATIVE WORK}

\subsection{Theme}

The subject matter of my story is human desire and the theme that I want to explore in my story is the power of human desire that drives human's choices. In my story, the power of Peter's desire is the one that drives him to exhibit his genital and also the one that drives him to fight his exhibitionism.

The theme is clearly shown in the story when Peter decides to exhibit his genital even though he does not really accept his exhibitionism. He has a trauma from his childhood which leads him to be an exhibitionist unwillingly. He tries his best to repress his desire to exhibit since he is unwilling to be one. However, his exhibitionism desire is too strong to be repressed. His exhibitionism desire which is human desire is indeed very powerful which drives Peter's choices. He ends up exhibits his genital even though after he exhibits it, he feels guilty and depressed. 
However, since he is not really willing to be an exhibitionist, he is able to leave his exhibitionism life once he finds a strong motivation for him, Camila. His love for Camila and his will for making her happy are both human desire. Human desire once again is very powerful and it drives human choices. In the context of my story, Peter's desire for Camila is driving him to fight his disorder even though it is very hard.

\subsection{Characters}

1. Peter Chandra

Age: 28 years old

He is an Iptu, Inspektur polisi satu. He looks normal from the outside, a well-mannered guy that is attractive. He is good looking and attractive, and has a well-built body shape. He is not a social type guy; he prefers having few but close friends. He does not really tell his problems, especially his exhibitionism problem to other people since he is afraid they will judge him. Especially, in the country he comes from Indonesia, it is considered taboo and most people do not have proper knowledge about exhibitionism. The only exception is Kevin, who is his childhood bestfriend. As a middle rank police officer, he has more responsibilities for himself and for the police department. He has to bear heavier consequences if his family or colleagues find his sexual deviation.

He does not really accept his sexual deviation. He always feels that he is such an awful monster. He really tries his best to pressure his urge and to be "normal" but he cannot help it. There's the time when he cannot hold it anymore. Holding it makes him going crazy, anxious and depressed. Once he releases it, he gets this exhilarating feeling, especially when the victims are not shocked, frightened or disgusted. Every time his victims afraid of him, he feels awful and uncomfortable. He does not have any intention to scare or cost any harm to anyone. However, once he finds a victim that is not afraid of him, he feels like it is the best day of his life since he is able to release his urge fully and not hurting his victim. However, after he does it, he feels that he is a monster since he does not really accept his exhibitionism behavior.

His exhibitionism act is triggered when he was 7 years old, his older sister and her boyfriend forced him to touch his sister's genital for helping them reached orgasm. After that day, there is always weird feeling that haunts him. When he was 10 years old his sister's boyfriend introduced him to porn. He tried to masturbate while watching it, but he doesn't feel right. He felt something's missing. On his 17th birthday, his first crush congratulated him. She was so pretty which made him turn on in a strange way. That was the first time he felt that he wanted to exhibit, right in front of her. He felt so anxious. He tried to masturbate but he cannot reach orgasm, instead he wanted to exhibit it. He felt something's wrong with him. He had the courage to exhibits when he was 25 years old, which was the very first time for him. In total he exhibits for 3 times.

His victim is usually pretty and good looking girls, around 20's something. Since he is a police on PPA department (Kanit Perlindungan Perempuan dan Anak) he has the benefit of knowing some similar cases that he uses as his scapegoat for his exhibitionism acts.

The method that he uses is flashing. He will conceal his genitals with a trench coat, newspaper, book, or similar object. When he sees a suitable victim, he will enter the victim's line of vision and expose his genitals to her. He shows his genital to his victims and after that he masturbates to the point of ejaculation in front of them. If the victims are afraid of him, he will masturbate to the memory of the event with awful feeling.

He does not make attempts to hide his identity since this additional risk-taking behavior is heightening his sexual arousal. That is why he chooses his location far from his home to reduce the 
possibility of being recognized by someone that knows him and at night to make the victim harder to see his face.

Camila becomes his motivation to fight his disorder. Since he loves her and he does not want to hurt her, he decides to go under the long term treatment of Trazodone pill. He really hopes that he is able to change before Camila finds out about his sexual deviation.

2. Camila Putri

Age: 25 years old

She is an Aiptu, Ajun inspektur polisi satu that works under Peter's supervision for some time. She is Peter's love interest and later on becoming Peter's girlfriend. She is pretty, attractive, cheerful, positive and extrovert person. She is a talented and hardworking police. She is able to impress Peter since their first mission.

She likes Peter from their first meeting, but she does not have any idea about who Peter really is. She tries to attract and impress Peter in any occasions. She is an open minded person and it is proven at the way she thinks about the exhibitionist. When she knows about Peter's exhibitionism, it shocks her which makes her remember her childhood. She really demands an explanation from him since she really cares about him. Her childhood experience and her love for Peter is sincere which makes her able to accept Peter's sexual deviation, even helps him.

Camila has a bad childhood as well. When she was 15 years old, her mom left her family since her mother felt ashamed of her own husband, Camila's father. His dad is a bipolar since he was a child, but it became worse when he was around 40's. It was very painful for her. There was the time when she wanted to leave him as well, but she could not. Somehow she knew that he did not want any of this to happen, but he could not control it. She knew if she left him, she would leave him in despair since no one supported him to fight his disorder and tried to give him a chance, so she decided to stay. Camila does not want to be like her mother. She thinks that her mother is a monster which makes her decide to stay with Peter and helps him.

3. Rachel Susanto

Age: 22 years old

She is a university student. She comes from the typical of "broken but rich" family and it ruins her life. She always feels like she is alone in this world. She tries to attract attention from her family with any means. She is suffering from nymphomaniac, a condition where a woman has abnormally excessive and uncontrollable sexual desire. This condition is shown when she forced Peter to have sex with her and her friend when Peter made them as one of his exhibitionism victims. It is shown again when she was charged of children molestation which made her met Peter again. And again, it is shown when she threatened Peter to have sex with her once she knows Peter's identity. She does not have any personal problems with Peter. The only thing that she need is attention. It is clearly seen that she seeks for attention when Camila tries to find information from her, she plays with her. She looks like she is enjoying it since she is able to feel the attention that she got from Camila. And when she is at the police station, she plays all of the officers there to make her to be the center of attention by doing it.

4. Kevin

Age: 28 years old

He is Peter's childhood bestfriend. He is the only person knows about Peter's exhibitionism behavior before Camila and Rachel find out. He is an open minded and understanding person. He believes that Peter is a nice person that does not mean any harm for anyone even though what Peter does is morally bad. He always supports Peter from the first time he know about Peter's exhibitionist act. He tries to persuade Peter to change and able to accept himself. He is always the one who Peter will call whenever there is problem, especially about girls. Kevin is always the one who persuades Peter to try to 
have a relationship with a girl since he hopes that the girl would be a strong motivation for Peter to fight his disorder. Kevin is able to understand Peter's condition fully and willing to support Peter since he knows about Peter's rough childhood that triggered Peter's exhibitionism behavior. He believes that good things will come for Peter someday.

5. dr.Carla Sutedjo, spKJ.

Age: 42 years old

She is Peter's psychiatrist. She is a professional in her field. She is a classy and simple person that is shown from her styles. She is a family typed person since she always puts her family first. It is proven from the way she encourages Peter to make Camila as his ultimate motivation to fight his disorder. His loved one is the only thing to heal Peter from his exhibitionism behavior.

6. Sarto Muklis

Age: 37 years old

$\mathrm{He}$ is a rapist that being captured by Peter and Camila on their first mission together. $\mathrm{He}$ is famous for being barcode rapist. He is accused of exhibitionism, kidnapping, raped, torturing by leaving some identical scars, barcodes on his victim bodies to mark them as a sense of ownership. He does everything that is listed except for exhibitionism. The one that exhibits is Peter. Peter uses his power to put his act on other culprit, making Sarto as Peter's scapegoat. His parent divorced and left him alone this is the triggered him to have the sense of ownership of the girls that he raped since he wants to have and belong into something. He is very obsessive and confident of himself.

7. Judy

Age: 24 years old

She is an officer that works more at the office rather than the field.

8. An exhibitionist guy at TP

Age: 45 years old

He is a stressful and depressed man that exhibits his genital. He is another type of exhibitionist. He does not afraid of revealing his exhibitionist act to crowded public. In fact, he tries to attract them since he finds it satisfying. His act triggered Peter to be more depressed since after capturing him, Peter feels that he is a really awful monster. Peter is able to feel and relate with the victims view of this exhibitionist guy.

9. Girl 2 / Rachel's friend

Age: 20 years old

She is Rachel's friend from the same university. She is Rachel's junior. She is suffering from nymphomaniac as well which is shown when she and Rachel forced Peter to have sex with them when Peter made them as his exhibitionism victims.

10. An unlucky university girl

Age: early 20's

She is one of Peter's exhibitionism victims. She is the type of scared exhibitionism victim.

11. Peter's older sister

Age: 36 years old (Age: 15 years old on flashback scenes)

She has completely different life with Peter. She is a nymphomaniac who accepted her sexual deviation. She is kind of harsh toward Peter. And she is the one who introduces Peter into sexual activity earlier than he should which triggers Peter's exhibitionism behavior.

12. Peter's older sister's boyfriend 
Age: 38 years old (Age: 17 years old on flashback scenes)

$\mathrm{He}$ is an abusive sex addict. He introduces Peter into sex life and porn on Peter's childhood life. $\mathrm{He}$ is also the one that triggers Peter's exhibitionism behavior.

\subsection{Conflict}

The major conflict of the story is man vs himself. Peter who is suffering from exhibitionism does not really accept his sexual deviation but he cannot hold his desire either. He feels guilty toward his victims and he does not want to harm them, but he cannot help it. As a police officer who has a middle rank, Iptu, he has more responsibilities for himself and for the police department. If his family or colleagues discover his sexual deviation, he has to bear heavier consequences. His conflict is getting more complicated when he meets a girl that he loves, Camila. He wants to be with her but he does not want to hurt her since he feels that he is such an awful monster. He does not want to hurt her like what he did to his ex-girlfriend because of his exhibitionism behavior. He decides to go under long term medical treatment to heal him. But, things never go easy on him. His long term medication treatment is having some side effects that make him suffered more. He has to hide this condition from Camila since he does not want to hurt her.

The minor conflict of the story is man vs man, when one of his exhibitionism victims, Rachel recognizes Peter and start to threaten him to have sex with her. Also when Camila starts to notice Peter's change in behavior and confronts him. And when Camila becomes more suspicious toward Peter since he is acting more weirdly after meeting Rachel and Camila tries to find it by her own which makes her confronts Rachel. The ending scene also belongs here, when Camila confronts Peter to confirm his exhibitionism.

\subsection{Settings}

1. Indonesia

My story takes place in Indonesia. All of sexual deviations problems are considered taboo and most of Indonesians do not really understand about exhibitionism. Mostly, they will cast out all of those that are suffering from sexual deviation.

\section{Police office}

Peter's office takes place at Polsek Sukomanunggal. This is the place where Peter and Camila meet everyday since they are working together as police officers. The scenes mostly taking place at Peter's room. Some of the scenes are taking place at basement, interrogation room when Peter interrogates Rachel and at a crowded shared office space where Camila tries to find some information about Peter and finds it.

\section{Police office - Peter's Room}

This is the place where Peter and Camila meet for the first time. A lot of important scenes are happening here as well, like when Peter contemplates whether to exhibits or not, Peter has quality time with Camila, Camila reveals her thought about exhibitionism and Peter confesses his feeling for Camila. His room is small, neat and simple.

\section{Peter's Apartment}

Peter's apartment will be located at Puncak Permai Apartment because it is closer with his office. This is the place where he is able to release his guilt after doing such thing since his house is the only safe place for him. The scenes that are located in here are taking place inside bedroom, bathroom, and living room. A lot of important scenes are taking place here as well like when he is depressed after 
flashing, when he is asking Kevin's advises about Camila, and also when Camila confronts Peter about his exhibitionism.

\section{Slum Area}

The slum area will be located at Bantaran Sungai Sepanjang. This is the place where Peter does his exhibitionism act. Besides it is safe for Peter since the slum area is far from his house, also he does it here since he has a scapegoat that he can use by putting his act on Sarto. This is the first place where Peter and Camila go on mission together, capturing Sarto. Sarto's house also located there.

6. Streets and alleys around Petra Christian University area

The third exhibitionism act happens at some streets and alleys around Petra Christian University area. Since Peter's target is young girls at college, this place is the most suitable for him since he will be able to release his urge by waiting for unlucky girl that is walking at the street or alley late at night alone. In this place, Peter meets Rachel for the first time where he exhibits his genital in front her and her friend.

7. Cafetaria near police office

The cafeteria is right across the police office. It is a small and simple depot. The maximum capacity of this depot is approximately for 50 persons.

\section{Tunjungan Plaza}

This mall is the biggest mall in Surabaya, located in the central of the city. This is the place where a stressful exhibitionist guy exposes his genital into the visitor's there. He chooses TP 3 since the architect of the building is shaped into a circle which would get him more attention for his act. This is also the place when Peter feels more depressed after he sees the reaction of the visitors about exhibitionism.

\section{Psychiatrist office}

The room is neat, clean and having fresh aromatic. The room's decoration style is classy by using wooden furniture and decoration. All of the comfortable sofas are also colored in brown. There is one long couch that is similar with Freud's sofa, where all of the patients lay there and tell their problems. These are purposely made to make the patients feel relaxed which will be very helpful for them to tell the psychiatrist about their problem. And one of the most important scenes is taking this place as well, where Peter decides to go under the long term treatment of medication.

10. Rachel's luxurious apartment

Rachel's luxurious apartment will be located at Ciputra World Apartment. This place is where Camila forces Rachel to give some information about Peter. In this apartment, we are able to see more about Rachel, a rich kid that is lack of family's attention. She lives alone here.

\subsection{Synopsis}

Peter is an Iptu or Inspektur polisi satu, who is also an exhibitionist. He does not really accept his sexual deviations but he cannot hold his urges as well. He always feels guilty for what he does. He feels awful when his victims are scared of him. He is worried of someone will find out his sexual deviations. One day, he meets Camila, an Aiptu or Ajun inspektur polisi satu who will work under his supervision. Both of them are attracted to each other. Peter, especially is attracted to her as a girl not as a victim. Since they are working together intensively, they get closer to each other in a very short time.

He really loves her, which motivates him to change into a better person. He wants to fight his disorder. He decides to go under long term medical treatment. The problems are starting to come, the side effects of the medicine started to affect him and one of his exhibitionism victims is threatening him which makes Camila know the truth about him. 


\subsection{Step Outline}

1. PETER is reading a file on his office. He looks anxious but after that he looks determined. He goes somewhere.

2. PETER exhibits his genital to an unlucky young girl which scares her. He does it at a slum area at night.

3. PETER takes a shower while tries to recall the exhibits act before and masturbates. However, he feels guilty and sad for the girl since he scares her off.

4. PETER meets CAMILA for the first time at the office. PETER is an Iptu while CAMILA is Aiptu that works under his supervision for a period of time. Both of them feel attracted to each other.

5. CAMILA observes PETER without his knowing when both of them eat at cafeteria near the police office. Here, she gets more information about him.

6. PETER gives CAMILA her first mission.

7. PETER teases and motivates CAMILA at the same time, right before they go to the mission place.

8. They arrive at the mission place which is a slum area that PETER went the night before. He explains about the mission, target, and tactic details to her. PETER tries to hide his guilty feeling toward the misaccused for their target, SARTO about his exhibitionism act. CAMILA tries to flirt with PETER, and PETER feels more attracted to her.

9. They go out from the car to capture SARTO.

10. They go in to SARTO house.

11. They ambush SARTO. Something distract them which make SARTO has the opportunity to run away from them.

12. CAMILA arrests him impressively. PETER gets more and more attracted to her.

13. CAMILA tries to get closer with PETER. PETER shows more affection toward her without realizing it. After CAMILA leaves his office, he contemplates about something.

14. PETER sits in his car while still contemplating about his exhibitionist act. He cannot hold his desires to exhibits, so he decides to do it.

15. PETER finds a perfect spot at the end of a random alley around Petra Christian University. He finds two young girls as the perfect victim for his exhibitionist act. It is a lucky day for him since both of the victims are enjoying his act. However, things turn out badly for him since both of the victims are forcing him to have sex with him. He keeps on resisting them since he does not want to have sex with just any one, only the one that he loves. And also, it is because he is not a pervert but a man that is struggle with an exhibitionism behavior which torture and please him at the same time. He is able to escape from them without hurting them.

16. He tries to masturbate again when trying to recall the recent exhibitionism act and feels happy about it since the victims are happy and enjoying it. But, once he recalls the little incident, he feels awful. Out of the blue, he thinks about CAMILA and feels happy about it. Without realizing it, he stops masturbate and think about her instead. He goes into a deep sleep.

17. Montages of them having quality time together.

18. PETER meets CAMILA at the office. When both of them are still in the middle of conversation, they receive a report of a suspicious guy at Tunjungan Plaza. They go there.

19. They arrive there, before the go in, PETER gives CAMILA some advises.

20. The suspicious GUY apparently is an exhibitionist that is flashing in front of the visitors there. They capture him and bring him to the office. However, when he catches the guy, PETER able to feel how weird an exhibitionist in the eyes of the visitors there. He feels depressed about it.

21. PETER feels depressed about the exhibitionist case. He stays at the office until late as usual. CAMILA comes in to find him, she offers him to work overtime. He is hesitant, but CAMILA convinces him that she wants to learn more from him, so he allows her. It gives them a valuable quality time. CAMILA discusses the recent exhibitionist case which makes PETER 
uncomfortable, but CAMILA's reaction on exhibitionism makes him feel better. They have a really great time which leads into more intimate moment. But, PETER feels bad for CAMILA since he thinks that he is a monster, so the situation turns awkward and he excuses himself first. It makes CAMILA confused.

22. PETER confuses and hesitates about his relationship with CAMILA. He is afraid that he will hurt CAMILA. He calls his best friend, KEVIN who is the only person that knows and understands about PETER darkest secret. PETER tells KEVIN about CAMILA, asking for his advises. Another thing about PETER get revealed, he had an ex-GF that left him after knowing his exhibitionism behavior. He is worried that CAMILA will do the same and he is afraid that she will get hurt because of him. KEVIN persuades PETER to try a relationship with CAMILA. He believes someday PETER will find someone who will able to understand and accept him without any condition, and it might be CAMILA. PETER asks KEVIN's opinion whether he should meet psychiatrist or not in order to change to be a better person. KEVIN completely support his decision. After they hang up the phone, PETER thinks about it deeply.

23. CAMILA meets PETER at his office. The situation turns a little awkward. CAMILA tries to change it by apologize to PETER for having the wrong idea about their feeling. PETER told her that she does not need to since she is right from the first time. He confesses to her that he likes her as well, since the first time they met. He kisses her.

24. PETER meets a psychiatrist, consulting his exhibitionism behavior . The psychiatrist tells him that he should go under long term treatment using Trazodone. PETER agrees to go under the long term treatment.

25. PETER and CAMILA just finished having sex. Both of them are naked and trying to sleep. CAMILA looks happy and into her deep sleep. While PETER, he cannot really sleep and feels anxious since he doesn't really feel satisfied with the "normal sex". He goes to the bathroom.

26. He tries to shower and masturbates. He tries to recall his sexual activity with CAMILA (scene 23) when masturbates, but he cannot do it. He does not feel right and cannot even reach climax. He tries to think about his exhibitionist act (scene 1 and 14) and he cannot reach orgasm as well, the effect of the medicine. He looks stressful and depressed. He feels guilty toward CAMILA.

27. PETER meets his psychiatrist for the $5^{\text {th }}$ times already. He tells her that he gets depressed lately since the effects of the medicine starts to affect him. He is worried that CAMILA will find out about it and it will hurt her.

28. CAMILA asks PETER whether he is okay or not since she feels something wrong with him. Suddenly JUDY comes in and asks PETER to do interrogation.

29. GIRL 1, RACHEL is the one that PETER has to interrogate. She recognizes him and tries to threaten him to have sex with her or she will spill the beans.

30. This make PETER acts strange and distant with CAMILA. CAMILA suspicious since PETER turns to be weirder after meeting RACHEL at the office. She tries to find out about PETER'S behavior.

31. CAMILA decides to find RACHEL which makes RACHEL realizes that CAMILA has a special relationship with PETER. Knowing this, she plays on CAMILA's emotional side which make her have more advantages toward PETER. CAMILA becomes more suspicious toward PETER.

32. CAMILA curious and tries to find more information. She reads all of the cases that had being handled by PETER. She reads all of them and finds some mismatches on some cases. She types something on her computer. She tries to connect it with RACHEL's clue. And she finds out the unpleasing information about PETER.

33. CAMILA confronts PETER. PETER confesses everything to her.

\section{CONCLUSION}

I would like to focus more on the main purpose of my screenplay. The main purpose is to make readers understand more about psychological problems which, in this case, exhibitionism. I tried to show 
the readers about the struggle of exhibitionist by letting them read and feel what is like to be an exhibitionist. And I tried to show them the efforts of exhibitionist to be "normal" sexually.

The first purpose is to show the struggles of exhibitionist through my main character, Peter. In my screenplay, I showed how he really felt about exhibitionism. He does not really accept his sexual deviation and he is depressed. It is shown in scene 2 and 14, where right before he exhibits his genital, he looks hesitate. He tries to control it, but his urge is stronger than him. At the end of scene 2, I showed how he really feels about his scared victim, he cries since he feels that he is such a monster. In scene 3 , he stops masturbating immediately after he remembers the reaction of his victim that was scared of him. He cried and depressed, he looks like he regrets what he had done. He realizes that his exhibitionism behavior is something that he should not do and nasty. It was shown at scene 20 , where he arrests an exhibitionist and sees the reaction toward the exhibitionist guy.

I am adding more struggle that exhibitionists have to go through even though they decided to go under long term treatment medication. It is shown clearly in scene 30 and 31 where Peter and Camila had sex and Peter could not really enjoy it. He feels really bad toward Camila and it makes him more depressed but in the other hand, it motivates him to change. I showed a reasonable history of Peter's exhibitionism where he was sexually harassed by his own sister which triggered his sexual deviation. This is shown in scene 25 where he consults to a psychiatrist about his exhibitionism and tells her the details of his exhibitionism act. I put all of these with a hope that readers able to understand more about exhibitionism and have empathy for them. Hopefully they will be able to help exhibitionist if they find one. And the most important thing is that after reading this screenplay, readers are realizing that sexual harassment can lead into a sexual deviation which very destructive. I really hope that such thing can be decreased in the near future.

The second purpose of my screenplay is to show the readers of Peter's effort to be "normal" so he can be a decent guy for Camila and his sexual deviation will not destroy their relationship. It is shown in scene 25 where Peter starts to consult his exhibitionism behavior to a psychiatrist since he feels that he is an awful monster. His efforts to change is clearly shown there since he is really determined to change and agrees to go under the long term treatment medication right away, even though the side effects are hard. Of course there is the moment where he wants to give up since the side effects are too hard for him which is shown in scene 32 . However, since he has a strong will to fight his disorder, he is hanging on.

I put those scenes in my screenplay in order to show the readers that some exhibitionists are having the effort to change as well, that they try their best. I want to encourage the readers to support them since it is really important for them being supported by their closest one which will make them more motivated to change. Therefore, I really hope that the readers of my screenplay will be more understanding toward them and will be able to support them, not cast them out. Thus, I give information to the readers that exhibitionism is actually can be healed, so exhibitionist will not give up to their sexual deviation since there is hope for them to be "normal". And even though they can be treated by medicine, the most important factor is actually the support of the closest one for them. I showed the readers in my very last scene, scene 38 , the reaction of Camila after knowing the truth about Peter. She is very supportive toward him, even she is willing to help him.

It is very important for us to be an open minded person, not a judging and close minded one. We have to try to be more understanding with their situation, feeling and struggle. Not only for the readers, but also for the exhibitionists, they have to be brave to come out to their closest one and ask their help and support to help them to change to be "normal". I hope that both of my purposes are able to make the readers becoming more open minded with this issue. And they will be more concern toward exhibitionists, not judging them as a nasty people. 


\section{REFERENCES}

Bonnet, J. (n.d). Writing Screenplays vs. Novels: A Tough Love Guide for Writers. Retrieved October 7, 2017, from https://www.writersstore.com/the-novel-vs-the-screenplay-a-tough-love-guidefor-talented-writers/

Brown, G. R., MD. (2015). Exhibitionistic Disorder (Exhibitionism). Retrieved September 5, 2017, from http://www.merckmanuals.com/professional/psychiatric-disorders/sexuality,-genderdysphoria,-and-paraphilias/exhibitionistic-disorder

Brown, G. R., MD. (2015). Overview of Paraphilic Disorders (Paraphilias). Retrieved September 6, 2017, fromhttp://www.merckmanuals.com/professional/psychiatric-disorders/sexuality,gender-dysphoria,-and-paraphilias/overview-of-paraphilic-disorders

Buffam, M. (2011). Drama. Retrieved April 10, 2018, from https://thescriptlab.com/screenplay/genre/952-drama/

Byrne, J.M. (Producer), \& Lazarus, T. (Director). (2002). The Exhibitionist Files [Motion Picture]. United States: Indigo Entertainment.

Canning, Iaian. (Producer), Sherman, Emile. (Producer), \& McQueen, Steve. (Director). (2011). Shame [Motion Picture]. United Kingdom: Fox Searchlight Pictures.

Carney, C., MD, MSc. (2016). Mental Illness in Society. Retrieved September 4, 2017, from http://www.msdmanuals.com/home/mental-health-disorders/overview-of-mental-healthcare/mental-illness-in-society

Cooper, M. (2012). Code and conventions of drama. Retrieved April 10, 2018, from https://www.slideshare.net/coopermatt62/codes-and-conventions-of-drama

Iliades, C, MD. (2014). What is Trazodone (Oleptro)?. Retrieved April 10, 2018, from https://www.everydayhealth.com/drugs/trazodone

Kurniawan, M.R. (2017). Terdakwa Eksibisionis Ini Sedikit Bernapas Lega, Loh... . Retrieved October 2, 2017, from https://www.jawapos.com/radarsemarang/read/2017/07/22/2786/terdakwaeksibisionis-ini-sedikit-bernapas-lega-loh

Law Officer. (2008). Indecent Exposure: Exhibitionism. Retrieved October 1, 2017, from http://lawofficer.com/archive/indecent-exposure-exhibitionism/

Lenora, K.M. (2017). Exhibitionistic Disorder: Cause, Symptoms, Treatment DSM-5. Retrieved October 1, 2017, from https://thriveworks.com/blog/exhibitionistic-disorder/

Mental Disorder. (n.d.). Exhibitionism. Retrieved October 1, 2017, from http://www.minddisorders.com/Del-Fi/Exhibitionism.html

Möller, L. (2015). An Exhibitionist Explains Why He Can't Just Stop Harassing Women. Retrieved October 17, 2017, from https://www.vice.com/sv/article/dp58ay/an-exhibitionist-explainedwhy-he-just-cant-stop-harassing-people-876

Prewitt, T. (2016). What It's Like to Be a Female Exhibitionist. Retrieved October 17, 2017, from https://mic.com/articles/143711/what-it-s-like-to-be-a-female-exhibitionist\#.OMrcAvaDL

Psychology Today. (2017). Exhibitionism. Retrieved September 2, 2017, from https://www.psychologytoday.com/conditions/exhibitionism

Sativa, R.L. (2017). Sederet Eksibisionis yang Masuk Pemberitaan Nasional. Retrieved October 2, 2017, from https://health.detik.com/read/2017/06/06/135524/3521746/763/3/sedereteksibisionis-yang-masuk-pemberitaan-nasional

Sex Info Online. (2014). Exhibtionism. Retrieved October 1, 2017, from http://www.soc.ucsb.edu/sexinfo/article/exhibitionism

Terao, T. \& Nakamura, J. (2000). Exhibitionism and low-dose trazodone treatment. Retrieved April 10, 2018, from https://www.ncbi.nlm.nih.gov/pubmed/12404312 